Remigiusz WĘGRZYNOWICZ, Bernard KŁYSZEJKO

Physiology

\title{
METHOD FOR APPLICATION OF PHYSICAL EFFORT TO FISH
}

\section{METODA OBCIAZZZANIA RYB OGOLNYM WYSIEKIEM FIZYCZNYM}

\section{Institute of Ichthyology *)}

A method was elaborated for application of physical effort to fish and for calculation of fish performance ability in physical units $(\mathrm{kGm})$.

The changes appearing in fish organism under dynamic effort represent particularly interesting problem in aspect of its adaptability to variations of environment (temperature, salinity, contamination etc.)'.

The existing methods permitted an observation or registration of motions frequency and locomotive velocity of hydrofauna (J o n e s, 1955; K a s im ov, 1961; K l e e rko per, et al. 1961; S p e n c e r, 1939; S pee r, 1941; S a burenkov et al. 1967).

To obtain more exact quantitative measurements, a method was elaborated for application of physical effort to fish with possibility of calculating the obtained results in work units $\mathrm{kGm}$.

Owing to reflexogenous reaction, a fish will move into deeper waters in case of any danger or when its liberty of motion may be hindered. Exploiting such reaction known in majority of fish, a device was applied to coerce the fishes to dynamic effort under aquarium conditions.

By this method, a ball float of determined force of buoyancy is fitted to base of dorsal fin approximately at centre of fish gravity. Basing on locomotive velocity, the effort of fish required to equalize buoyancy force of float $\left(F_{\mathrm{w}}\right)$ in determined time, was calculated in physical units $(\mathrm{kGm})$.

Specific weight of fish, owing to reflexive regulation of gas pressure within the air-bladder, corresponds approximately to specific weight of environment for determined depth at which the fish remains. A float fitted to dorsal fin represents additional force acting vertically upwards. A fish resisting the force which is pulling it upwards to surface, is, coerced to intensive work which is proportional to buoyancy force of float. It ascertained experimentally that, the fishes such as Rutilus rutilus (L.), Abramis brama (L.), Perca fluviatilis L., Tinca tinca (L.), Anguilla anguilla (L.), equibalanced buoyancy force of float by continous swimming in horizontal plane, in diagonal position, or down-headed under angle of $20^{\circ} \pm 3^{\circ}$ to water surface and their swimming speed amounted approximately to $0.125 \pm 0.015 \mathrm{~m} / \mathrm{sec}$. In tests performed on 5 mentioned species ascertained that, about $90 \%$ of swim-

*) From Ex-Department of Fish Physiology 
ming time with attached float prevailed on locomotive motion in vertical plane. Fish motions in other planes were rather sporadic (particularly at beginning of test) and therefore are considered as admissible errors in calculations.

Friction force of floats at speed of $0.125 \pm 0.015 \mathrm{~m} / \mathrm{sec}$, calculated according to Stokes formula, did not exceed on average $2 \%$ of floats buoyancy force; this permits to consider friction force as non essential in further calculations. To calculate buoyancy force of float, following formula was applied :

$$
\mathrm{F}_{\mathrm{w}}=\mathrm{g} \mathrm{V}\left(\mathrm{d}_{\mathrm{c}}-\mathrm{d}_{\mathrm{p}}\right)
$$

where: $\mathrm{F}_{\mathrm{w}}$ - buoyancy force of float $(\mathrm{N})$

$$
\begin{aligned}
& \mathrm{g} \text { - accelleration of gravity }\left(\mathrm{m} / \mathrm{sec}^{2}\right) \\
& V \text { - volume of float }\left(\mathrm{m}^{3}\right) \\
& d_{c} \text { - density of water }\left(\mathrm{kg} / \mathrm{m}^{3}\right) \\
& d_{p} \text { - density of float }\left(\mathrm{kg} / \mathrm{m}^{3}\right) .
\end{aligned}
$$

$$
\begin{gathered}
\mathrm{m} / \mathrm{sec} .{ }^{2} \mathrm{~m}^{3} \mathrm{~kg} / \mathrm{m}^{3} /=\mathrm{m} / \mathrm{kg} / \mathrm{sec}^{2} /=(\mathrm{N}) \\
\mathrm{F}_{\mathrm{w}}(\mathrm{kG})=\frac{1}{\mathrm{~g}} \mathrm{~F}_{\mathrm{w}}(\mathrm{N})
\end{gathered}
$$

Graphic distribution of forces (simplified) acting on fish swimming in plane parallel to surface with fitted float of buoyancy force $F_{w}$ is presented in fig. 1.

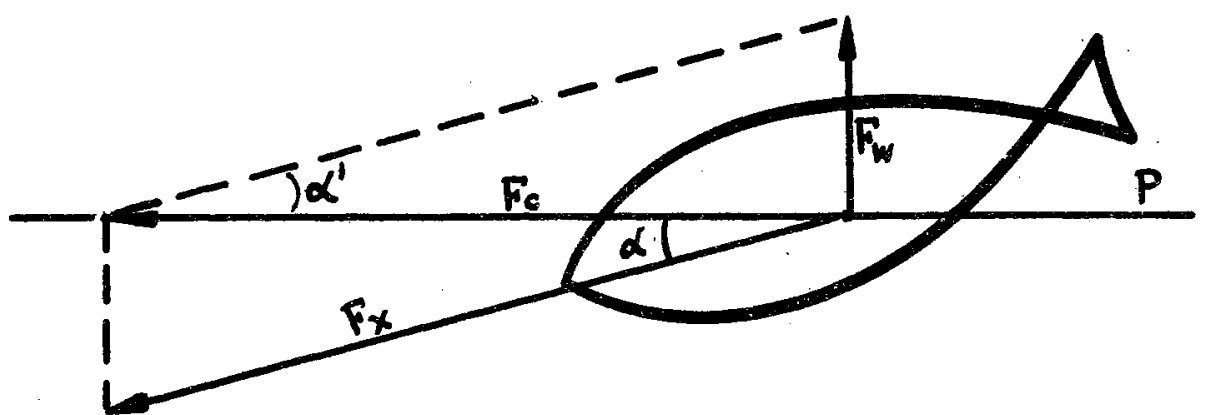

Fig.1. Graphic distribution of forces (simplified) acting on fish swimming in plane parallel to surface with fitted float of buoyancy force $F_{w}$

It is apparent from fig. 1 that, the force $F_{C}$ may be expressed by formula:

$$
\mathrm{F}_{\mathrm{c}}=\mathrm{F}_{\mathrm{w}} \operatorname{ctg} \alpha
$$

fish travel is defined by formula:

$$
\mathrm{S}=\mathrm{vt}
$$

where: $s$ - fish travel (m)

$\mathrm{v}$ - fish speed (m/sec.)

$\mathrm{t}$ - swimming time (sec.). 
The work performed by fish may be expressed as:

$\mathrm{L}=\mathrm{F}_{\mathrm{c}} \mathrm{s}$, what

after substitution of value $F$ from formula 2) gives final formula for fish work which swims with float ${ }^{c}$ of determined force of buoyancy, giving:

5)

$$
\mathrm{L}=\mathrm{F}_{\mathrm{w}} \mathrm{s} \operatorname{ctg} \alpha(\mathrm{kGm})
$$

where: $\mathrm{L}$ - work of fish $(\mathrm{kGm})$

$\mathrm{F}_{\mathrm{w}}$ - buoyancy force of float $(\mathrm{kG})$

$s^{w}$ - travel of fish (m)

$\operatorname{ctg} \alpha$ - angle between longitudinal axis of fish and plane of water surface.

Thus, dynamic work performed by fish was calculated from product of float buoyancy force, of travel and of angle comprised by water surface and longitudinal axis of fish. Elaborated method permits for control of fish dynamic effort under determined conditions of environment. Qualification of physical effort in units of work may be applicable as basic method for study of metabolic changes in aspect of fish adaptability. Initial studies on biological tests framed within the investigations of environments contaminated with toxic substances, also prove the usability of this method.

\section{ACKNOWLEDGEMENT}

Authors are expressing deepest appreciations and thanks to dr Jan Budzin$\mathrm{ki}$, the Adiunct of Physics Team from Institute of Agriculture Mechanisation of Agriculture Academy Szczecin, for His kind consultations in elaborating the formulas applied in this work.

\section{REFERENCES}

J o ne s F.R.H., 1955: Photokinesis in the ammocoete larva of the brook lamprey., J. Exper. Biol., 32, 3: 492-503.

K a s i m o v R.J., 1961: Sutocnyj rytm dvigatelnojaktivnostividov osetrovych ryb i ich gibridov. - Zool. zurn., T.XI, 1: 63-71.

K l e e rko pe $r$, T a yl 1 r G., W i l t o n R., 1961: Diurnal periodicity in the activity of Petromyzon marinus and the effects of chemical stimulation. - Trans. Amer. Fish. Soc., 90, 1: 73-78,

S p e n c e r W.P., 1939: Diurnal activity infresh-water fishes., Ohio J. Sci., 39, 3: 119-132.

S p o $\circ \mathrm{r}$ W.A., 1941: Apparatus for measuring activity of fishes. Symposium of Hydrobiology. Univ. Visconsion Press.

S aburénkov E.N., S bikin J., . Pawłow D.S., 1967: O skorosti dvizenija ryb. - Izd. Nauka, Moskva. 


\section{METODA OBCIĄŻANIA RYB OGÓLNYM WYSİKIEM FIZYCZNYM}

\section{Streszczenie}

Opracowano metodę obciążania rybogólnym wysiłkiem fizycznym w warunkach akwaryjnych.

Metoda polega na umocowaniu do płetwy grzbietowej pływaka o określonej sile wyporu. Pracę fizyczną wykonaną przez ryby obliczano z iloczynu siły wyporu pływaka, przebytej drogi oraz ctg kąta zawartego pomiędzy powierzchnią wody a osią podłużną ciała ryby.

Opracowana metoda pozwala na sterowanie dynamicznym wysiłkiem ryb jak również może być zastosowana przy badaniu zmian metabolicznych w aspekcie zdclności adaptacyjnych.

ВИДОВЫЕ СПОСОБНОСТИ РЫБ К ДИНАМИЧЕСКОМУ ФИЗИЧЕСКГМУ УСИЛИЮ ABRAMIS BRAMA (L.), RUTILUS RUTILUS (L.), PERCA FIUVIATILIS L. ANGUIILA ANGUILLA ( L.)

$$
\text { P e } 3 \text { to } M \text { e }
$$

.Проведены сравнительные определения способности к динамическому физическому усилию четырёх видов рыб (Perca fluviatilis (L.) Abramis brama (L.) Rutilus rutilus (L.), Anguilla anguilla(L.) в аквариумных условиях при использовании авторсокого метода нагрузки общим ф̆изическим усилием,

В исследованиях определены предельные величины выталкивания поплавка, при которых исследуемые рыбы выполняли непрерывные ритмиеские поступательные дивжения в течение двух часов, не проявляя признаков уссталости. Затем увеличили рабочую нагрузку до появления признаков острого утомления .

В результате исследований установлены ऋачительные видовые различия в способности к динамическому усилию.в определённых условиях среды.

Address :

Received 15.VI.1.1972

Doc.dr Remigiusz Węgrzynowicz

Instytut Ichtiologii AR

Szczecin, ul. Kazimierza Królewicza 4

Polska - Poland 